\title{
WATER PRESSURE UNDER A GLACIER
}

\author{
By W. H. Mathews \\ (Department of Geology, University of British Columbia, Vancouver, Canada)
}

\begin{abstract}
Observations in a deep mine working which reached the base of a valley glacier some $150 \mathrm{~m}$. below the ice surface indicated an initial cold and impervious condition at and near the ice-rock contact. Later, however, an excellent hydraulic connection with free water in the upper layers of the glacier was established, perhaps by the thawing of a passage upward through the ice by warm water escaping from the mine. Subsequent records of water levels, or of water pressures, within the mine, reflecting conditions in the upper part of the glacier, show periods of moderately steady conditions, at times showing slight diurnal fluctuations, interrupted by irregular and catastrophic surges, particularly during periods of rapid snow melt and heavy rains. A seasonal cycle in pressure is suggested by the record.
\end{abstract}

RÉsumÉ. Des observations effectuées dans un tunnel profond d'une mine qui a atteint la base d'un glacier de vallée à quelques 150 mètres au-dessous de la surface de la glace, ont montré qu'il existait à l'origine, au contact des roches avec la glace et à proximité de celle-ci, des conditions de froid et d'imperméabilité. Plus tard, cependant, s'est établie une connexion hydraulique excellente avec l'eau libre des couches supérieures du glacier, peut-être par suite du dégel d'un conduit montant à travers la glace à cause de l'eau chaude qui s'échappait de la mine. Des enregistrements des niveaux d'eau ou des pressions hydrostatiques, effectués postérieurement à l'intérieur de la mine en vue d'indiquer les conditions régnant dans la partie supérieure du glacier, montrent des périodes où les conditions sont moyennement régulières, au moment des fluctuations diurnes légères, périodes qui sont interrompues par des inondations irrégulières et catastrophiques, particulièrement pendant les époques de dégel rapide et de grosses pluies. Les données d'observation suggèrent un cycle saisonnier des pressions.

Zusammenfassung. Beobachtungen im tiefen Stollen einer Mine, der bis zur Sohle eines Talgletschers etwa ${ }_{1} 50 \mathrm{~m}$ unter der Eisoberfläche hinunterreichte, liessen anfänglich einen kalten und undurchlässigen Zustand an und in der Nähe der Berührungsfläche zwischen Eis und Fels erkennen. Später jedoch stellte sich eine ausgezeichnete hydraulische Verbindung mit dem freien Wasser in den oberen Schichten des Gletschers ein, vielleicht durch das Schmelzen eines Leitungssystems aufwärts durch das Eis infolge von Warmwasseraustritten aus der Mine. Anschliessende Registrierungen des Wasserspiegels oder des hydrostatischen Wasserdruckes in der Mine, die den Zustand der Gletscheroberschicht wiederspiegeln, zeigen Perioden annähernd stetiger Verhältnisse mit gelegentlichen kleinen Tagesschwankungen an, unterbrochen durch unregelmässige und katastrophenartige Ausbrüche, besonders in Zeiten schneller Schneeschmelze und heftiger Regengüsse. Die Aufzeichnungen deuten einen jährlichen Druckzyklus an.

\section{INTRODUCTION}

Subglacial water pressure is considered to play a very important part in a number of aspects of glaciology and soil mechanics. Haefeli (1957, p. 27-29), for example, has suggested that seasonal variations in water pressure at the ice-rock contact may be responsible for seasonal variations in the rate of flow of the overlying glacier. In this Haefeli applied the concepts of Terzaghi (Terzaghi and Peck, 1948) in the role of hydrostatic uplift in landsliding, and subsequently of Hubbert and Rubey (1959), and Rubey and Hubbert (1959) in the part played by water pressure in the mechanics of overthrusting. Weertman (rg62) has offered a theory that catastrophic advances of some glaciers are made possible by a water layer at the bottom of the glacier and that the velocity is influenced, among other things, by the pressure of this layer. Mathews and Mackay (1960) have discussed effects of subglacial water pressure, with and without accompanying permafrost, in the deformation of sediments by overriding glacier ice. Moreover, in the compaction of loose sediments by the load of overlying glacier ice, the differences between total load and the hydrostatic pressure within the pores of the sediment is an essential factor. All the discussions on these subjects to date have, however, been hypothetical because of the lack of direct information on fluid pressures beneath a glacier. Several hydrologic problems exist in the consideration of subglacial water pressure:

(I) Can the main body of the glacier be considered as an impervious layer separating a "free ground-water system" in open crevasses, moulins, etc., near the surface from a confined ground-water system beneath the ice, or is there hydraulic continuity between the basal contact of the glacier and the surface in the same vicinity? 
(2) If there is hydraulic continuity between the surface and bottom of a glacier, is it established through large continuous openings offering a free connection, or is it limited by very low permeabilities such as may exist along crystal boundaries within the ice (Bader, I950)?

(3) Is there, indeed, considering the temperatures that may exist deep within the glacier, any liquid phase there at all? Similarly, considering the temperatures that may exist at the glacier floor, is there any liquid phase in the rocks immediately beneath the ice or does the glacier rest on permafrost?

By virtue of variations in temperature, depth, extent of fracturing and perhaps crystal size, it cannot be expected that the same answers to these questions apply to all glaciers, to all parts of a single glacier, or even at all times for a single point within a glacier.

A few answers to these problems have come from the Granduc Mine (lat. $56^{\circ}{ }^{\prime} 2^{\prime} \mathrm{N}$., long. $130^{\circ} 20^{\prime}$ W.) in the northern Coast Mountains of British Columbia where one exploratory tunnel driven in 1957 made contact with the base of South Leduc Glacier $150 \mathrm{~m}$. below the ice surface (Fig. I), about $2 \mathrm{~km}$. up-glacier from the terminus and $6 \mathrm{~km}$. from its head.

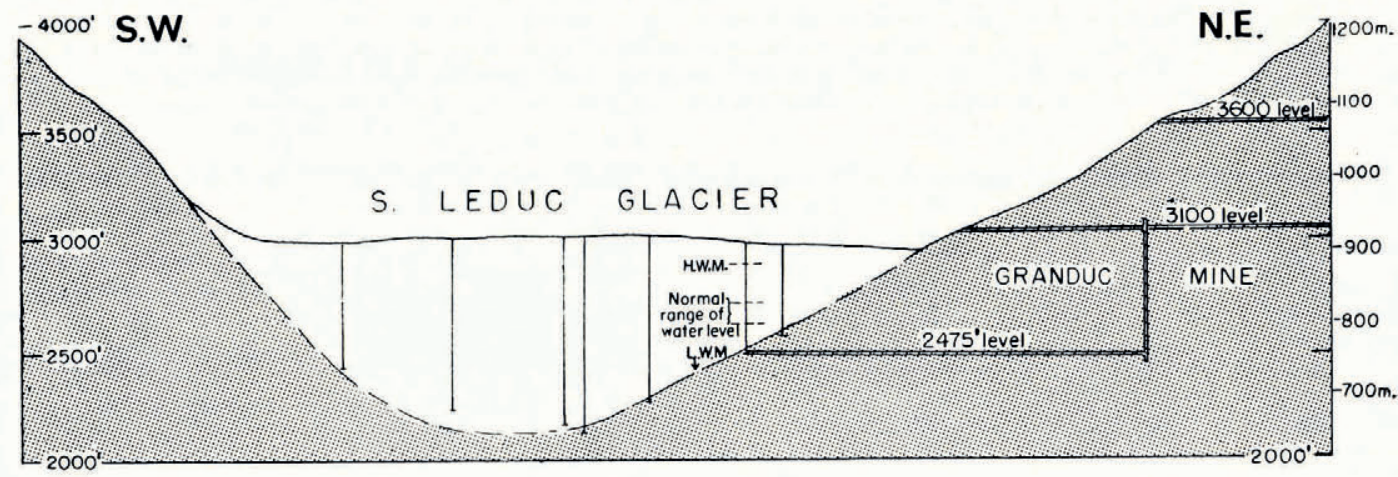

Fig. I. Profile trending $040^{\circ}$ east across South Leduc Glacier at Granduc Mine, showing mine workings and drill holes in the glacier

Although records of water pressure subsequently obtained here are far from continuous, sufficient data are now available for all seasons of the year to provide some answers to the questions raised above.

\section{The Record}

The 2475 level (so named for its elevation, in feet above sea-level, at the mine shaft) of the Granduc Mine, the working which made contact with the glacier, was driven in 1957 as part of an exploration program of the large Granduc copper deposit. The level itself was terminated about $\mathrm{r}$ m. short of the glacier and three horizontal holes were drilled from the tunnel face into ice or frozen moraine to test, among other things, whether it would be possible to dispose of mine water into the glacier. None of the holes, however, would accept water even under pressures of 7 to $20 \mathrm{~kg} . / \mathrm{cm}^{2}$ ( 100 to $300 \mathrm{lb} . / \mathrm{in} .^{2}$ ) (Mathews, 1959). To facilitate drilling of ore bodies in this vicinity two raises were cut at the end of the level to a height of about $6 \mathrm{~m}$. and one of these broke out of bedrock into "frozen moraine". No water was reported to have flowed from this raise at the time (Walsh, r963, p. 86) and the ice-bedrock or morainebedrock contact can be considered as having been then essentially impervious.

After this drilling program was completed in the spring of $195^{8}$ pumps were withdrawn from the shaft, the mine was closed, and the shaft and lower workings were allowed to become flooded. Until exploration of the deposit was renewed in the spring of 1961 , very few observa- 
tions were made of conditions in the lower workings, but four spot observations (personal communication from Dr. G. W. H. Norman) in 1959 and I96o (Fig. 2) showed that the water level in the shaft could vary by as much as $105 \mathrm{~m}$. and could fall as low as the level of the top of the raise which had broken out of bedrock.

In $196 \mathrm{I}$, when exploratory work at the mine was recommenced, the writer arranged for the installation of a water-level recorder in the shaft and this provided almost continuous observations from 8 May to the following October. Very great fluctuations in water level, commonly associated with periods of heavy rain led to difficulties in the operation of the recorder and it was withdrawn on 2 October.

In April i 962 attempts were begun to de-water the shaft and lower workings of the mine (Walsh, 1963), and these continued until their successful conclusion in September of that year. Pumping alone proved insufficient; the operation of pumps at rates of more than $4,500 \mathrm{l}$. $/ \mathrm{min}$. ( $\mathrm{I}, 200 \mathrm{gal} . / \mathrm{min}$.) had no continuing effect on water level. Accordingly, in July and August the end of the 2475 level was partly sealed off by forcing in a mixture of sand, gravel and cement through three $10 \mathrm{~cm}$. (4 in.) diameter holes drilled vertically into it from the surface of the glacier. At the end of August the workings were finally pumped out. The seal at the end of the 2475 level proved not to be completely watertight, permitting leakage in from the glacier at a rate of 600 to $75^{\circ} \mathrm{l} . / \mathrm{min}$. and, briefly, for $4,500 \mathrm{l}$. $/ \mathrm{min}$. It did make it possible to work in the 2475 level in moderate safety. However, for full security a concrete bulkhead $3 \cdot 7 \mathrm{~m}$. thick was then set $3^{8} \mathrm{~m}$. short of the end of the working. A Bourdon gage, mounted on a pipe extending through this bulkhead and read daily, has provided a record (from early October ig6i to early May 1962) of water pressures on the glacier side of the bulkhead. From this latter record the head (level of the free static water surface) has been computed to compare with earlier readings of water level within the shaft (Fig. 2).

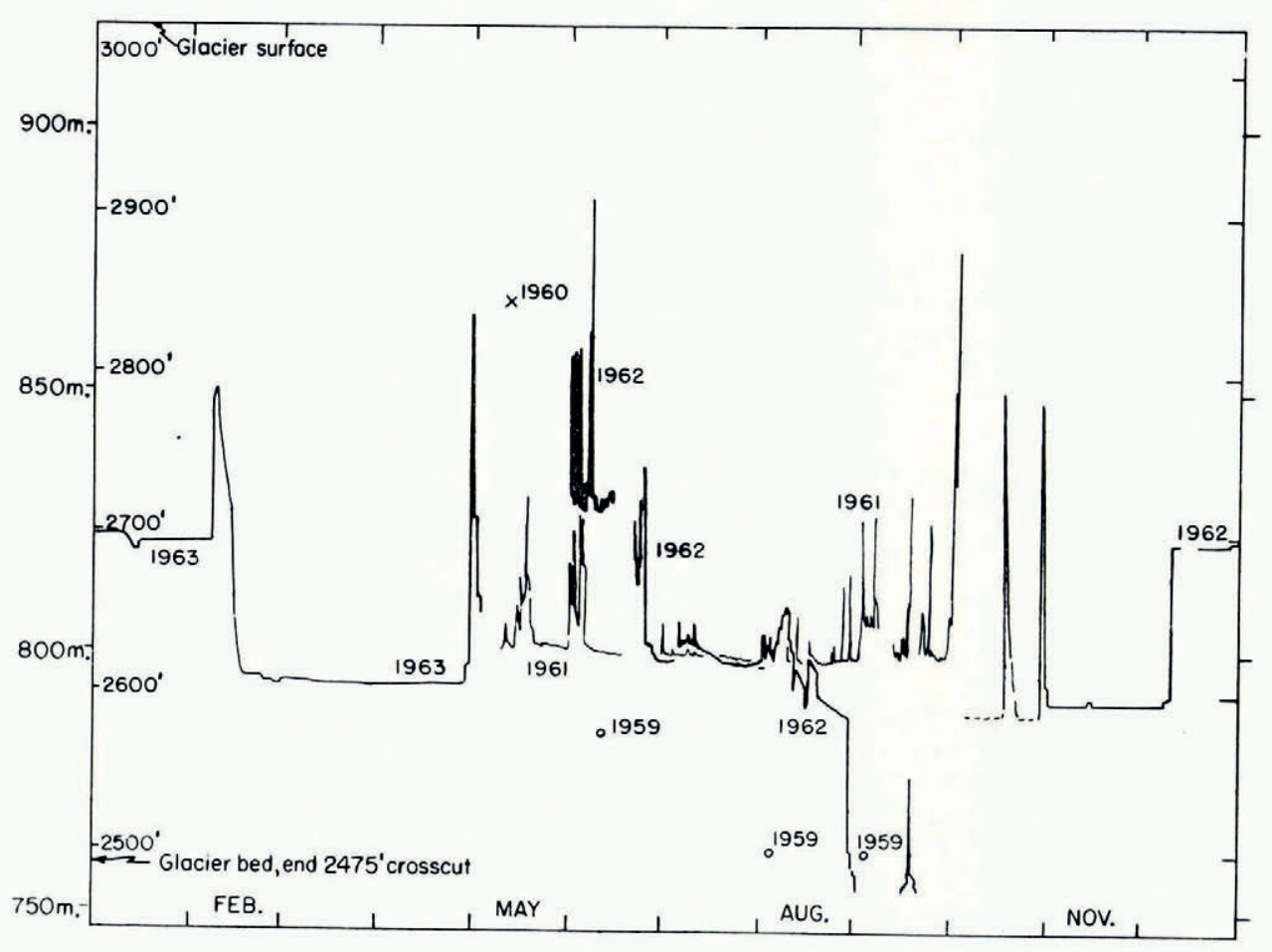

Fig. 2. Water levels in South Leduc Glacier at Granduc Mine 
In May 1963, when the second drilling program from the 2475 level was completed, pumps were again withdrawn and the workings were allowed to flood pending a decision on the future of the mine. No regular record of water level in the shaft has been kept since that date, but rare spot observations indicate that it has become approximately stable about $40 \mathrm{~m}$. below the shaft collar or about $25 \mathrm{~m}$. below the nearby glacier surface (elevation $2,875 \mathrm{ft}$. (877 m.)). A hydraulic connection between the shaft and the upper part of the glacier, perhaps along fractures in the ore zone at relatively shallow depth, is thus suggested. The extent of fluctuations induced either by variations in ground-water flow in the vicinity of the shaft or by variations in the water-table within the glacier are not known.

\section{Surface Velocity of the Glacier}

Four instrumental observations during 1963 on a stake set in the glacier above the end of the 2475 level indicate ice movement in a fairly constant direction at rates of from $7.0 \mathrm{~cm}$. day (over a 35 -day period) to $9.5 \mathrm{~cm}$./day (over a 17 -day period). No qualitative observations indicating any catastrophic movement, however short-lived, have been reported in the history of the mine.

\section{Mine Temperatures}

A few temperatures, taken with a thermistor and telethermometer having a scale range from $-5^{\circ} \mathrm{C}$. to $+5^{\circ} \mathrm{C}$., are now available from the mine. These have all been observed under circumstances designed to minimize any disturbing influence of circulating air or water from other parts of the mine, of mechanical heating by recent drilling or seasonal fluctuations, and the instrument has been repeatedly checked in ice water to eliminate index error.

In the uppermost level, 3600 , of the mine the rock temperature is about $+4 \cdot 2^{\circ} \mathrm{C}$., and on the main level, $3^{100}$, at the head of the shaft it is in excess of $+5.4^{\circ} \mathrm{C}$. Water issuing from cracks and drill holes in the 3600 level ranged from +3.6 to $+5 \cdot \mathrm{o}^{\circ} \mathrm{C}$. in July 1962 ; water on the 3 I 00 level and in the shaft was warmer than $+5 \cdot 4^{\circ} \mathrm{C}$. On the other hand, temperatures in the rock between the 2475 level and the base of the glacier were below zero. One reading in a drill hole $3 \mathrm{~m}$. above the 2475 level was $-1 \cdot 9^{\circ} \mathrm{C}$. and a second $9 \mathrm{~m}$. higher was $-2 \cdot 5^{\circ} \mathrm{C}$. The position of the ice-rock contact in the vicinity of the latter observation is in doubt, but it could be as little as $2.4 \mathrm{~m}$. or as much as $30 \mathrm{~m}$. higher. By linear extrapolation, the temperature at the base of the glacier might be from $-2 \cdot 7^{\circ} \mathrm{C}$. to $-4 \cdot 3^{\circ} \mathrm{C}$. and in any case is well below the pressure melting point of ice $\left(-\mathrm{O} \cdot \mathrm{I}^{\circ} \mathrm{C}\right.$. at a depth of $5^{\circ} \mathrm{m}$.).

\section{Discussion}

During and since I96I the water levels within the mine clearly respond to changing conditions within the adjacent glacier. To be sure these levels can have been influenced to some degree by leakage of water into the shaft from the adjacent rocks. This leakage, which has averaged about $75^{\circ} 1 . / \mathrm{min}$. and has reached about twice this rate, is reported to vary noticeably, after about a $12 \mathrm{hr}$. delay, with precipitation or snow melt at the ground surface and it undoubtedly decreases, other factors remaining constant, with a rise of water in the shaft. Nevertheless, the great rate at which water could enter or leave the workings, the lack of any continuing effect of pumping until the bulkhead was installed, and the fact that the water level has on occasions fallen to the elevation of the break-through to the glacier, all indicate there was established a very effective connection with some system of water-bearing cracks or passages in the glacier. The large volumes of water involved in some of the surges, the diurnal cycle obvious in late summer (on days when precipitation and snow melt on hillsides overlooking the glacier were lacking), and the steady water levels that prevail for extended periods all indicate a connection with an unconfined water system within the glacier. 
It is inferred, therefore, that the water level in the mine shaft and, later, the pressure at the bulkhead reflect approximately the level of the free water surface in the upper part of South Leduc Glacier. However, when this free water surface has fallen below the elevation of the raise, or the drill hole at the end of the 2475 mine working, the water in the shaft was able to fall to, but not below, this elevation. The extreme low water level in the glacier must lie at an unknown distance below the break-through, i.e. below altitude $2,505 \mathrm{ft}$. $(763 \mathrm{~m}$.).

"Base levels" at which the water surface commonly persists for extended periods, except during short-lived surges, may be established by spillways somewhere down-stream along the glacier. A search on the northern edge of South Leduc Glacier in July ig62 revealed two abandoned spillways which might have served to establish a persistent water level near the mine. These consisted of two nearly horizontal sub-parallel and sub-marginal tunnels which had evidently been occupied by large streams of water during the preceding year. In July I 962 , they were empty save for small rills which were thawing miniature meandering channels, Io to $20 \mathrm{~cm}$. wide and up to $60 \mathrm{~cm}$. deep, through the frozen stream water of the tunnel floor down to underlying moraine. The opening of a similar tunnel at a lower altitude could produce a sharp drop in base level such as occurred in late June and again in late August I 962 , or in February I 963 . The closure of a tunnel, conversely, could account for a sharp rise in base level such as occurred in December 1962 .

A seasonal cycle in base level is suggested but not demonstrated beyond all question; low base levels seem to occur in late summer and higher base levels in winter.

"Surges", striking and at times catastrophic but short-lived rises in water level, are commonly, but not invariably, associated with heavy rains (e.g. the surges of 2 October I96i and 7 February r 963 ; see Figure 2) and appear to be produced chiefly by water running into crevasses. Some surges occurring during dry weather may, however, be caused by the sudden release of water previously impounded in one or more chambers or crevasses up-stream within the glacier. Collapse of partitions between adjacent chambers as they, in turn, become drained may account for the multiple peaks of some of the surges (Mathews, ig63). Surges common in May and June may be caused, or triggered, by rapid run-off from snow melt, although no diurnal cycle is apparent in the record for these months.

Assuming that the pattern of water levels of $1961-63$ is typical and that a seasonal cycle is real, a winter increase in the rate of flow of South Leduc Glacier, such as suggested by Haefeli (1957), could be expected. It is possible, however, that extreme subglacial pressures associated with surges are more important, notwithstanding their short duration, than high base levels in promoting movement. In this case maximum velocities might occur in early summer during a period of rapid snow melt, and in early autumn during periods of high rainfall. By the same token the conditions most favourable for ice thrusting in the bed of the glacier might also occur at times of surges rather than at times of high base levels. The effect of this pattern of water levels on consolidation of underlying sediments would be difficult to predict. Escape of pore water, essential for consolidation, is possible during periods of low water, but it might be largely or completely inhibited at times of high water. In any case, complete consolidation by ice load could be greatly delayed by the existence of periods of high water.

The conditions recorded since 196r at Granduc Mine may not be typical of anything but the shallow terminal and marginal parts of a glacier. Access to the base of the glacier of relatively warm mine water, perhaps under high pressure when the workings were abandoned and flooded in 1959, may have created and enlarged an artificial passage through the ice to the surface layer of the glacier. The water-free condition of the ice-rock contact in 1958 , the inability of the drill holes to accept water, and the low rock temperatures immediately above the 2475 level all suggest an impervious condition in this vicinity. Here, water may normally exist in the liquid state only in capillary openings, along crystal boundaries, and in the presence of any local concentration of salts. The rock beneath the ice may be in a perennially 
frozen state for some tens of meters below the glacier and impervious except in the vicinity of any open water course through which passes a continuous flow of warm water.

This second condition, that of a deep, cold, impervious layer of ice resting on permafrost, would preclude a basal water layer and hydrostatic uplift as a cause for basal slip of the ice. Thrust faulting in the rocks of the glacier bed might still occur but displacements would most likely take place near the base of the permafrost rather than in the vicinity of the ice-rock contact (Mathews and Mackay, I960). Consolidation of sediments by ice loading would be very seriously retarded unless there were a continuous and pervious aquifer within them leading continously to some point near the glacier terminus which could permit escape of pore water under relatively low head.

That this second condition may also occur in other "temperate" glaciers is suggested by the presence of permafrost, to a depth of at least $20 \mathrm{~m}$., in volcanic ash covered by a small mountain glacier or recently exposed by its retreat, some 500 miles $(800 \mathrm{~km}$.) south-east of Granduc Mine (Mathews, I955).

\section{Summary}

The evidence from the Granduc Mine is interpreted as favoring under natural conditions an essentially impervious state for all but the shallower and marginal parts of the overlying glacier. Low temperatures within the basal part of the glacier and in the substratum may be largely responsible for this state and it may be characteristic of other mountain glaciers at mid latitudes as well as for bodies of ice in polar regions. Where, however, for natural or artificial reasons, a hydraulic connection exists between the glacier bed and glacier surface, there can be expected persistent water levels (and basal pressures) fluctuating slightly daily, somewhat more so in an annual cycle, and exhibiting irregular short-lived surges associated with floods of water on or in the glacier.

\section{Acknowledgements}

The writer acknowledges the invaluable aid provided in this study by the Granduc Mining Company and its staff over a period of 7 years; and the assistance in aspects of the work offered by the Canadian Water Resources Branch, the President's Research Fund of the University of British Columbia, and the Geological Survey of New Zealand.

MS. received 3 December 1963

\section{REFERENCES}

Bader, H. 1950. The significance of air bubbles in glacier ice. Journal of Glaciology, Vol. 1, No. 8, p. 443-5 I.

Haefeli, R. 1957. Notes on the formation of ogives as pressure waves. Fournal of Glaciology, Vol. 3, No. 21 , p. $27-29$.

Hubbert, M. K., and Rubey, W. W. 1959. Role of fluid pressure in mechanics of overthrust faulting. I. Mechanics of fluid-filled porous solids and its application to overthrust faulting. Bulletin of the Geological Society of America, Vol. 7o, No. 2, p. I $15-66$.

Mathews, W. H. 1955. Permafrost and its occurrence in the southern Coast Mountains of British Columbia. Canadian Alpine fournal, Vol. 38, p. 94-98.

Mathews, W. H. 1959. Glaciological work in western Canada, 1958. Canadian Alpine Journal, Vol. 42, p. 72-73.

Mathews, W. H. 1963. Discharge of a glacial stream. Organisation Météorologique Mondiale et Association Internationale d'Hydrologie Scientifique. Symposium. Eaux de surface, tenue à l'occasion de l'assemblée générale de Berkeley de l'Union Géodésique et Géophysique Internationale, $19-8-31-81963$, p.290-300.

Mathews, W. H., and Mackay, J. R. r 960 . Deformation of soils by glacier ice and the influence of pore pressures and permafrost. Transactions of the Royal Society of Canada, Ser. 3, Vol. 54, Sect. 4, p. 27-36.

Rubey, W. W., and Hubbert, M. K. I959. Role of fluid pressure in mechanics of overthrust faulting. II. Overthrust belt in geosynclinal area of western Wyoming in light of fluid pressure hypothesis. Bulletin of the Geological Society of America, Vol. 7o, No. 2, p. 167-205.

Terzaghi, K., and Peck, R. B. 1948. Soil mechanics in engineering practice. New York, John Wiley and Sons, Inc.

Walsh, D. C. I963. Reclaiming the shaft of Granduc Mines. Western Mineral and Oil Review (Vancouver, B.C.), Vol. 36 , No. 3 , p. 86-93.

Weertman, J. I962. Catastrophic glacier advances. Union Géodésique et Géophysique Internationale. Association Internationale d'Hydrologie Scientifique. Commission des Neiges et Glaces. Colloque d'Obergurgl, 10-9-18-9 1962, p. $3 \mathrm{I}-39$. 